\title{
Feedback Strategies Which Social Sciences Teachers Give to Their Students
}

\author{
Mehmet Akpinar \\ Department of Turkish and Social Sciences Education, Fatih Faculty of Education, Karadeniz Technical University, Turkey
}

Copyright $(2018$ by authors, all rights reserved. Authors agree that this article remains permanently open access under the terms of the Creative Commons Attribution License 4.0 International License

\begin{abstract}
This study tried to define the feedback strategies of social sciences teachers and their opinions about the content of the feedback. The study was carried out with phenomenological design which is one of the ways of qualitative research methods. The data that was collected by semi-structured interview form for the research was provided through descriptive analysis. The study was administered to 33 social sciences teachers at secondary schools in Trabzon province. As a result, it was determined that the teachers give feedbacks both verbally and written with a positive attitude. Moreover, the feedbacks were provided individually. They give their feedbacks both at the beginning and at the end of the class, and they use the progressive rating key in the process of feedback. Eventually, it was found out that teachers give feedback regularly and these feedbacks are reaching to children through the right evaluation function. As a result, it was also seen that teachers consider the capacity of each child while they give feedbacks to them openly.
\end{abstract}

Keywords Social Studies, Feedback, Feedback Strategies, Social Sciences Teacher

\section{Introduction}

Education is a process during which society transmits all its values to next generation [1].According to Sönmez [2], education is a formation of terminal biochemical changes in the brain as a result of physical stimulations. Educationis defined as the process of reaching the individual to the intended targets. Individuals gain knowledge, ability, attitude and value during this process. The individuals who gain knowledge, ability, attitude and value cause changes in the communal living [3]. Individual may have problems in getting into these changes occurring in the communalliving. Social sciences lessons have an essential task in finding solutions for these problems which were experienced [4], because social sciences is a lesson which reveals the interaction of people with their social and physical environment in the past, today and in the future [5]. Also, social sciences teachers have the most critical task in conveying the content of the social sciences lesson which has an essential place in our lives, to the students. While the teachers are transmitting the content of the lesson to the students, they benefit from the feedback strategies which are the most important factors in determining the quality of teaching services $[4,6]$.

It is a fact that feedback promotes and enhances teaching and learning. A lot of studies which base on the effect of feedback on these issues have been done, and the number of the studies investigating the teacher feedback in terms of students' learning in the classroom has been increasing. Feedback functions as a bridge between the teacher's pedagogical targets and students' learning needs. Besides, feedback is vital for the improvement of the knowledge and skill that students need. It also provides strong information about revealing the teachers and students performance. At this point, feedback is an important factor in creating learning needs. Cohen (1985) defines feedback as a strong and crucial tool in designing learning [7]. Hattie and Timperley (2007) identify feedback as the necessary knowledge which is given by others such as teacher, administrator, colleague, parent in order to make students understand their performance. Teachers tell students especially what is right or wrong in their feedback [8].

The content of the feedback (to be conveyed) can be categorized into five: (a) corrective feedback - the type and the extent of the mistake are stated and the ways to correct the mistakes are suggested; (b) non-corrective feedbackthe type and extent of the mistake are stated; (c) general feedback - evaluative feedback is given; (d) positive feedback - when a certain teaching behaviour is shown, it is praised, and (e) specific feedback -it gives objective information about a certain teaching behaviour that is previously determined.

Feedback provides students, teachers and administrative with the process of developing ideas and opinions. Besides, effective feedback depends on the characteristics of the 
students' capacity and motivation and the differences of intended learning outcomes. Hattie and Timperley (2007), claim that feedback reduces the differences between information and understanding, and between the obtained learning results and expected results. Teachers and students can reduce this difference with an effective feedback [8].

Hattie (1999) conducted a mega-analysis on factors affecting learning achievement in over 500 cases and it was found out that feedback was among the top five factors affecting learning achievement [9]. Marzano (2006) stated in his study that the feedback which is given as right or wrong has a negative impact on students and reduces success $3 \%$. On the other hand, the feedback given by stating the reasons why it is right or wrong has a positive impact and increases success $8,5 \%$. The feedback provided by giving the evaluation criteria increases success $16 \%$. The study revealed that as the teacher determines the feedback strategies according to the students' levels, its effect increases [10]. Also there are many studies on feedback, some of which have looked at the effects of different kinds of corrective feedback [11,12], while others have compared different types or combinations of form-focused and content-focused feedback [13, 14].

Feedback strategies include feedback, correction and clue. Feedback consists of the knowledge about which attitudes students learn and which students do not learn thoroughly. This knowledge, which is reached to teachers, is called feedback [15]. Correction is the teacher's expressing the existing deficiencies by completing them [2]. Feedback and correction which are among the feedback strategies are important elements in learning and teaching process. Because the informing process related to whether the students gain the intended attitude in the learning and teaching process, and at which level they gain these attitudes ensured with feedback and correction [6]. Showing performance and giving informative feedback are the stages which should be closely spaced [16]. Therefore, feedback, correction and clues should be used in teachers' training according to the rules [17].

Within this context, it is essential to determine social sciences teachers' opinions about feedback strategies. When thesis studies that were done on feedback strategies in previous years are reviewed, it is seen that Somuncuoğlu (1996) investigated the effects of different feedback strategies in computer-assisted teaching on learning [18]. Also, there are some studies that refer to learning strategies which are used in the classroom environment [19, 20,21]. Bolat (2008) also investigated the effect of teaching strategies on academic achievement [4]. In other similar articles existing in the literature, it is seen that Erişen (1997) studied the levels of instructors' feedback and correction behaviours [6]. Can (2005) studied the role of clues and reinforcers in teaching and learning [15], Çetinkaya and Köğce (2014), studied the feedbacks which Turkish and Mathematics teachers give to students [22], and Akalın (2014), studied teachers' professional development with performance feedback [23]. When the studies that were carried out before in the literature were regarded [7-14, 21-26], it was established that there are studies about feedback strategies in different fields [27, 28, 29, 30]. However, based on the reached resources it was determined that there is not any study about feedback strategies in social sciences field. It is thought that this study is the first in this sense. The study was carried out to fill this gap and to inspire the next researches.

\subsection{Aim of the Study}

The aim of the study is to determine the feedback strategies which socials sciences teachers use in their lessons. This study focuses on the factors for social sciences teachers' feedback content and their presentations to their students. In the light of this aim, this study tried to answer several questions about preferred feedback strategies and its reasons, the phase and amount of feedback given in lesson, the aim of the given feedback, providing individual and collective feedback, the content of the given feedback, the criterion of the content of the feedback, type of feedback perceived by the students, given positive or negative feedback, factors to be considered when giving feedback, coverage of feedback and effect of language used in feedback given in the lesson by the social sciences teachers.

\section{Materials and Methods}

This study was carried out based on the qualitative research approach. Qualitative researchers investigate the individuals' attitude and behaviours in details and try to reveal the reason and results of this attitude and behaviours rather than using experimental and certain facts. In this study phenomenology design which is one of the qualitative research designs was used. In phenomenology design, it is aimed at revealing common practices and defining and explaining the meanings which were created by the participants [31]. In this design, in addition to the interest and experiences related to the concerned phenomenon in individuals, the environment and conditions that these experiences occur are examined [32]. Thus, it is tried to reveal the perceptions related to the experiences which are realised but not known deeply [33]. The phenomenon which is handled in the study is "feedback" phenomenon. Phenomenology design which includes semi-structured interviews was usedto see the feedback practices that social sciences teachers use, to reveal the feedback strategies they use, their reasons, frequency, criterion and aspects that they pay attention while they are giving feedback. In other words, this study tried to reveal the features of the feedbacks that social sciences teachers use and the meanings that they attribute to these feedbacks by investigating the social sciences teachers' feedback experiences. 


\subsection{Sample Group}

The sample of the study consists of 33 social sciences teachers who taught in secondary schools in Trabzon province in 2014-2015. The participants were chosen according to convenience sampling which is one of the purposeful samplings. In the city, there are many social sciences teachers who have different experiences. Face-to-face interviews were done with many teachers and volunteers were selected to participate in the study. And 33 social sciences teachers are identified as sample. In this sampling method, the researcher chooses a close and accessible situation. By this way, the study gains speed and practicality [34].

\subsection{Developing the Data Collection Tool}

A semi-structured interview was administrated as the data collection tool in the study. Since the interview is carried out to reveal the reference person's interest, opinion, attitude and behaviour, enables to get information about a topic in details and frequently used in phenomenology design, it was used in this study [34, 35, 39]. While the interview was being prepared, firstly the literature was reviewed, and the studies which are about the feedback strategies in teacher training were determined. Secondly, in accordance with the aim of the study and the studies done in literature, draft interview form was formed. To increase the validity of the form, two academicians who are expert on social sciences education were asked for their opinions, and a pre-study was carried out with two social sciences teachers who were not involved in the sample group. By received feedback, the form was finalised. The interview questions of the data collection tool are:

1. Which feedback strategies are preferred by social sciences teacher for their students?

2. When and how often do social sciences teachers give feedback to their students?

3. What are the aims of social sciences teachers while they are giving feedback?

4. How do social sciences teachers realise giving individual and collective feedback?

5. How do social sciences teachers determine the content of feedback?

6. What is the content of giving feedback?

7. Which criteria affect social sciences teachers content of the feedback?

8. What is the type of feedback perceived by the students?

9. How are social sciences teachers' feedback classified?

10. How do social sciences teachers ensure coverage of feedback?

\section{What is the effect of language used in feedback?}

During the interview, related to the questions that were established before, the questions such as "Why?", "When?", "Can you explain it a bit more?" were asked when necessary in order to help to find out the teachers' opinions.

\subsection{Collection and Analysis of the Data}

The data related to the study were collected in2014-2015 academic year. At the first stage, the participants were provided with files which included the summary of the aim of the study and the prepared interview forms electronically or face to face. At the second stage, the period to realise the interview was established. At the last stage, face to face interviews were carried out by the researcher, and the obtained data were recorded. The data obtained from the study were analysed via content analysis. The reason is that content analysis enables to analyse a text profoundly and systematically with the codes based on some specific rules by dividing it into small parts, it finds out the individuals' interest, believes, attitudes and opinions, and it is suitable for the study [36]. Validity and reliability studies related to the data analysis were doneto have a sound basis. Full texts of the interviews were written down, and participants reviewed them to ensure the validity of the data analysis, and researcher triangulation which is one of the triangulation types was donein order toprovide reliability [32,37]. Within this context, one social sciences education expert and one social sciences teacher analysed the interviews independently apart from the researcher. The results of the analyses were compared,and its percentage was estimated as $80 \%$ [38]. The data which did not match were not involved in the analysis process, and the data were categorised as models. The teacher responses which are suitable for being an example for each category were presented to the reader without making any change. Regarding the ethics of the study, the identities of the teachers who participated in the interviews were concealed,and they were given codes such as T1, T2, and the data of the study were supported with the direct quotations.

\section{Findings}

In order to determine the feedback strategies that social sciences teachers applied in their lessons, they were asked questions in the semi-structured interview form, and models were preparedto show the distribution of the obtained data according to the categories. 


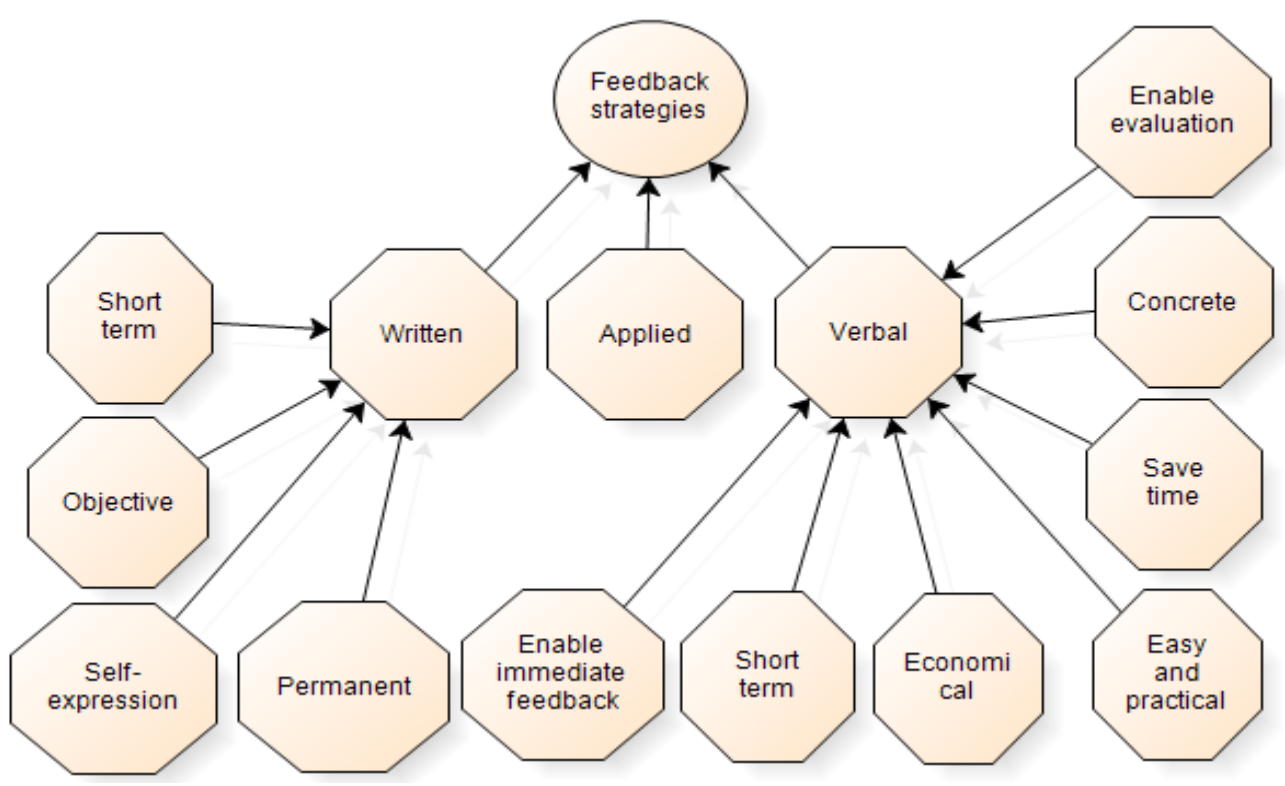

Model 1. Feedback strategies and preference reasons

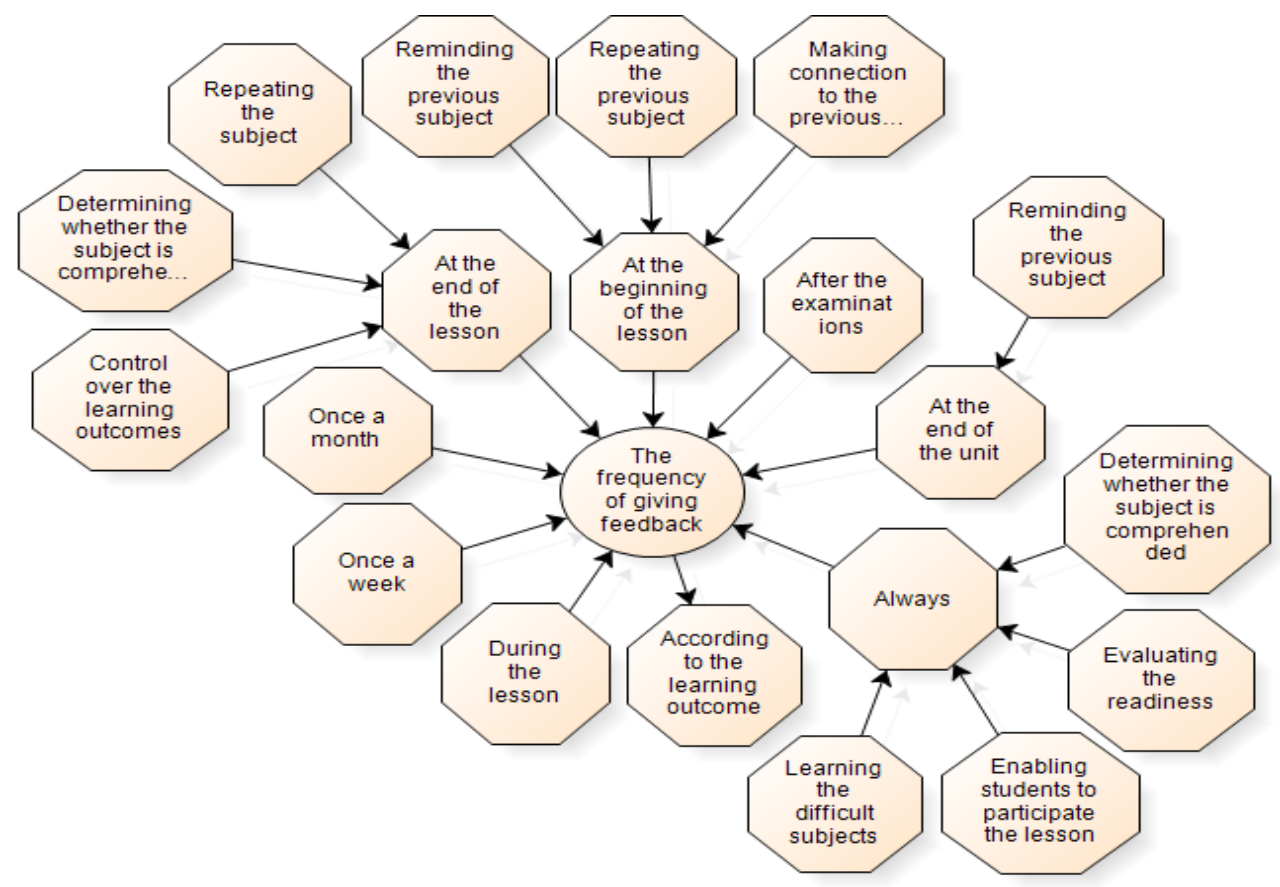

Model 2. Frequency of giving feedback and reasons of preference

As it is seen in Model 1, social sciences teachers prefer verbal, written and applied feedback strategies respectively. 25 of the teachers use verbal feedback strategy. The teachers stated the reasons of using verbal feedback strategies as taking little time, being economical, occurring easily and practically, saving time, being concrete and face to face, being appropriate for giving immediate feedback and it also enables to evaluate more than one student. T7 who is one of the teachers using verbal feedback strategy stated that "I mostly use verbal feedback type. My preference reason is it's being easier and more practical and saving time. Feedback is important regarding students' evaluating themselves and seeing their deficiencies." 23 of the teachers use written feedback strategy. The teachers who use written feedback strategy explained that they use it since it is objective, takes little time, permanent, and it enables students to express themselves well. T9 who is one of the teachers using written feedback stated that "I mostly use written feedback. Since verbal and applied feedback takes much time in a class of 40 students, written feedbacks are more sensible. Besides, in verbal feedbacks students cannot express themselves well and they may feel embarrassed. That makes them nervous." Two teachers use applied 
feedback. The reason for teachers' preferring applied feedback less is it's taking much time and being difficult.

According to Model 2, the teachers giving feedback occasions are like that respectively; at the end of the lesson (19 people), at the beginning of the lesson ( 8 people), after the examinations ( 7 people), at the end of the unit ( 7 people), at each stage ( 7 people), according to the learning outcomes ( 4 people), during the lesson ( 3 people), once a week ( 2 people) and once a month (2 people). The teachers mostly give feedback at the end of the lesson because they can repeat the taught subjects, they can determine whether the students learn the issues, and they can ensure the control of learning outcomes. T10 who is one of the teachers who give feedback at the end of the lesson stated that "I usually use feedback at the end of the lesson practices to understand whether the subject is understood and internalised. I sometimes use feedback at the beginning of the lesson in order to establish whether the subject to be learnt, is learnt sufficiently by referring to the previous subject." T3 who is among the teachers giving feedback at the beginning of the lesson in order to make a connection with the previous subject and to revise the subject stated that "I give feedback at the beginning of every lesson. I revise the previous lesson. Therefore, connection with other subject is established."T14 who is one of the teachers who stated that s/he always uses feedback expressed that "Feedback should be at every stage of teaching in order to measure readiness level, to determine the level of comprehension, to pinpoint the learning outcomes, to enable students to participate the lesson actively, and to progress together during the process.'T11 who is one of the teachers who use feedback at the end of the unit stated that "I prefer using feedback at the end of the units. By this way, previous subjects are remembered and reinforced."

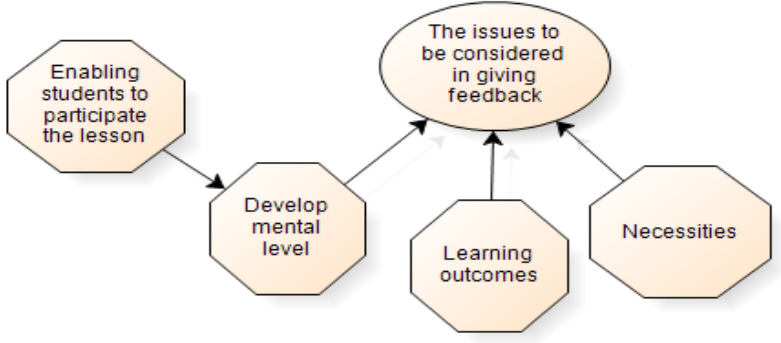

Model 3. The aim of giving feedback

According to Model 3, 25 of the teachers who give feedback stated that they give feedback considering the students' developmental levels, 17 of them by considering the learning outcomes, 7 of them use feedback to enable students to participate the lesson. The reason why teachers consider developmental levels while giving feedback is that they want to make each student participate the lesson. The most considered factor after the developmental level is learning outcomes. T7 who is one of the teachers giving feedback by considering learning outcomes stated that " $I$ give feedback according to the learning objectives. Feedbacks change according to the levels of classes. If the student prepares for an exam, feedback level increases. We consider the students' developmental levels. I give feedback,more especially to successful and prominent students. I can not say that I give effective feedback to the students who are not so successful." On the other hand, T11 who says that $\mathrm{s} /$ he gives feedback considering the students needs, stated that "We determine according to the students' level of learning the subjects. We use feedback mainly to reinforce the issue. We consider the learning objectives and the points that students need."

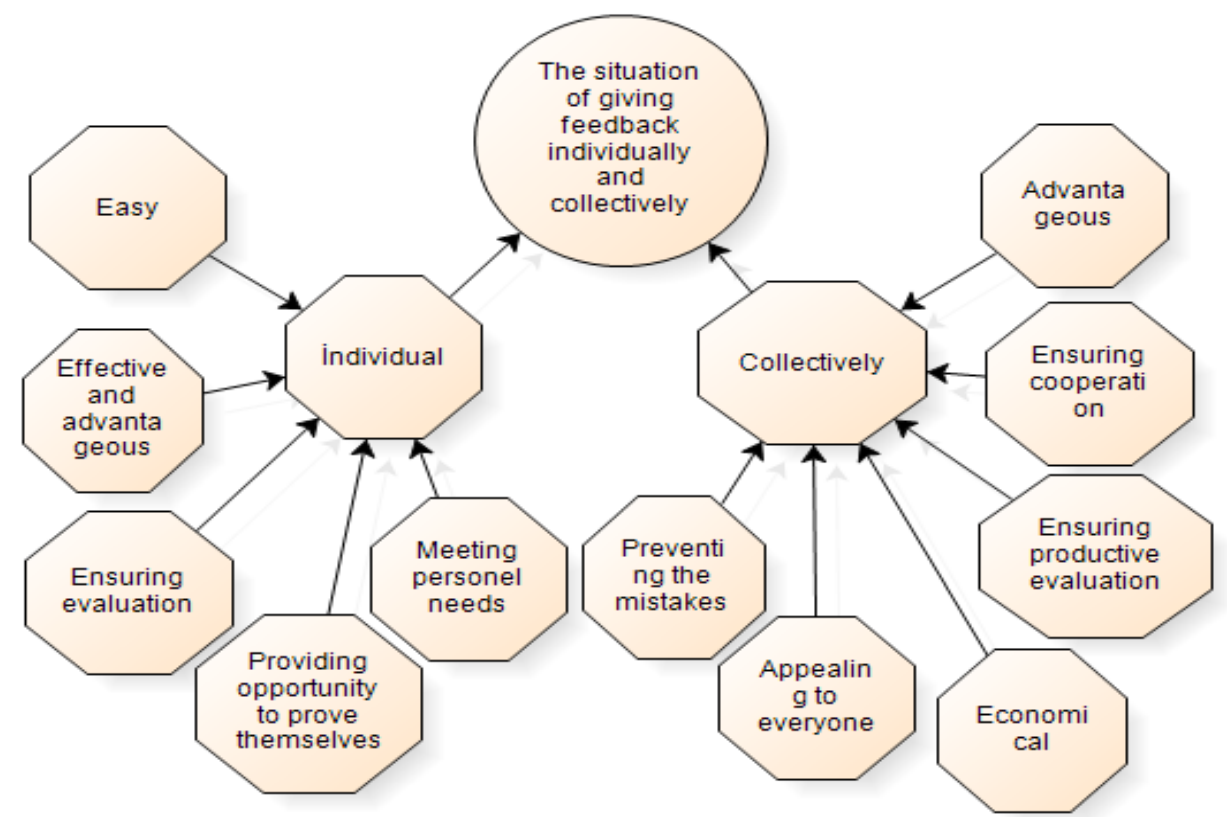

Model 4. The state of giving feedback individually and collectively 
According to the results obtained from Model 4, 23 of the social sciences teachers use individual feedback. The reasons why teachers mostly use personal feedback are providing a better evaluation, supplying the students' needs, enabling students to make an effort to prove themselves, and being easier compared to group work. Besides, teachers express that group work is not always advantageous in every class. As an example, T18 stated that "I think that individual informing is more advantageous in terms of students and teachers. By this way, students' deficiencies are seen and made up quickly. Its advantage for the teacher is that; it satisfies a need with less effort." 16 of the teachers claim that giving feedback towards a group is more advantageous. The reason for their preferring group feedback is taking less time to evaluate, being economical, addressing to the whole class, providing cooperation and agreement culture. Besides, they express that it is more productive and it prevents making the same mistakes compared to the individual feedback. As an example, T 14 expressed that "It is advantageous for students regarding cooperation, work sharing, and sense of unity, group mind, and comprehension. The evaluation process is shorter for the teacher, and it is useful for the values education."

As it is seen in Model 5, social sciences teachers associate the content of feedbacks to the students' organising themselves, the studies, the period of studies and the students' personalities. 16 of the teachers stated that they give feedback torealise the learning completely. Regarding the subject, T18 stated that "I think that this is the most important factor in determining the student's abilities and individuality." Some of the teachers (11 teachers) draw attention to the fact that they give feedback according to the individual differences because each student has a different comprehension capacity and level. While some other teachers (10 teachers) state that they give feedback to the students'study itself since the process is important, some teachers (10 teachers) stated that they give feedback to the process of the study in order to gain the learning outcomes. Related to the subject, T7 stated that "We have guidance hours during the personal relations in giving feedback related to the student's personality. However, if it is a study related to the group, I evaluate their behaviours in the group."

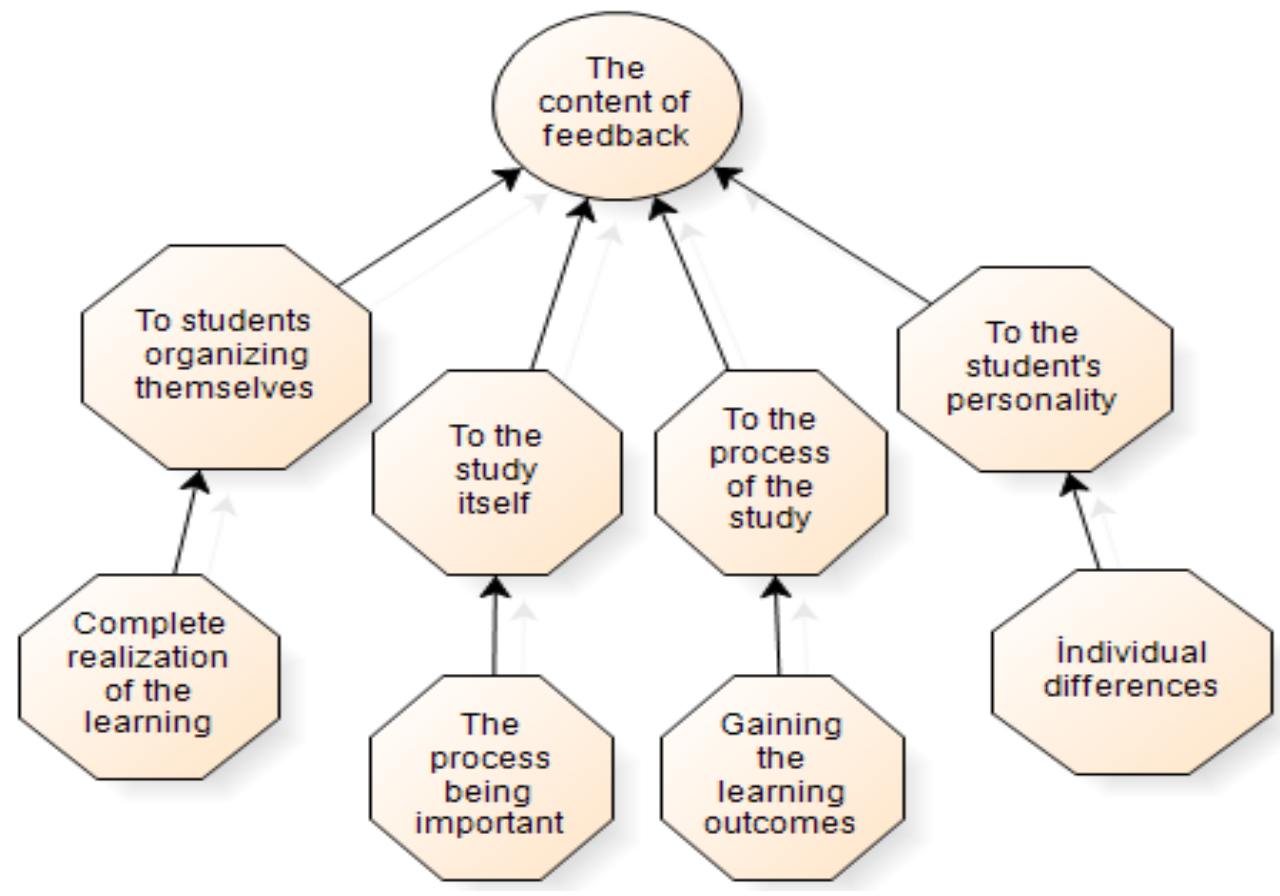

Model 5. The content of feedback 


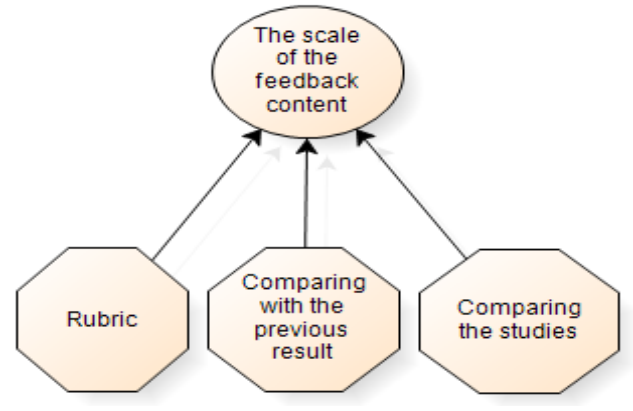

Model 6. The criteria of feedback content

According to Model 6, the scale which teachers use mostly in giving feedback to the students are respectively rubric (17 teachers), students' comparing themselves to their previous performance (12 teachers), and comparing students' works to other students' works (4 teachers).

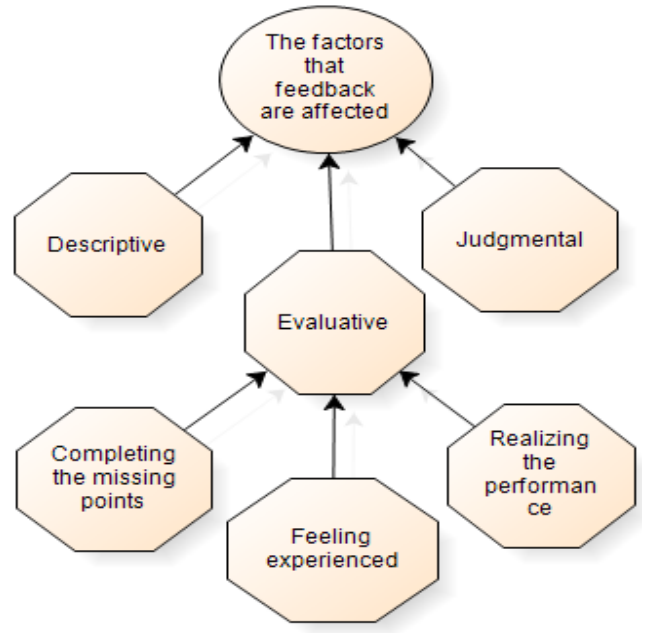

Model 7. The type of feedback perceived by the students

Based on Model 7, 15 of the teachers indicated that they are affected by the descriptive factors, 14 of them are influenced by individual evaluative factors, and 4 of them are affected by judgemental factors. T8 who stated that students would have an evaluative function as a result of the feedback given to the students indicates that "It reveals the students' evaluative sides. They can see their situation, whether they understand the subject or not, and their inadequacies and mistakes." T7 indicates that "I mostly give feedback with an evaluative approach. As a result of the informing, students learn their situation, their success and any incorrect information or experiences about the subject if any." As a result of the feedback given to the students, the teacher will have seen their missing points and mistakes and they will feel informed and experienced. Besides, they will notice their performance.

According to Model 8, while 24 of the teachers stated that they give positive feedback, 5 of them indicated that they use negative feedback. The teachers who provide positive feedback explained the reason why they are in a positive attitude as; to motivate students, to gain students our values, contribute to the students' personalities, to increase students' self-confidence, to motivate students for the lesson, to gain students, and to increase the students' motivations. Related to this subject, T1 stated that "I try to reveal the positive sides. I do not directly show their inadequacies, but I present them an example, and I try to make them notice their inadequacies." T10 indicates that "Of course, we sometimes give negative feedback. However, we try to give mostly positive feedback. Instead of saying these are wrong in a study that we see as mistaken or inefficient; we motivate them by saying what would be better." The teachers who give negative feedback explained its reason.

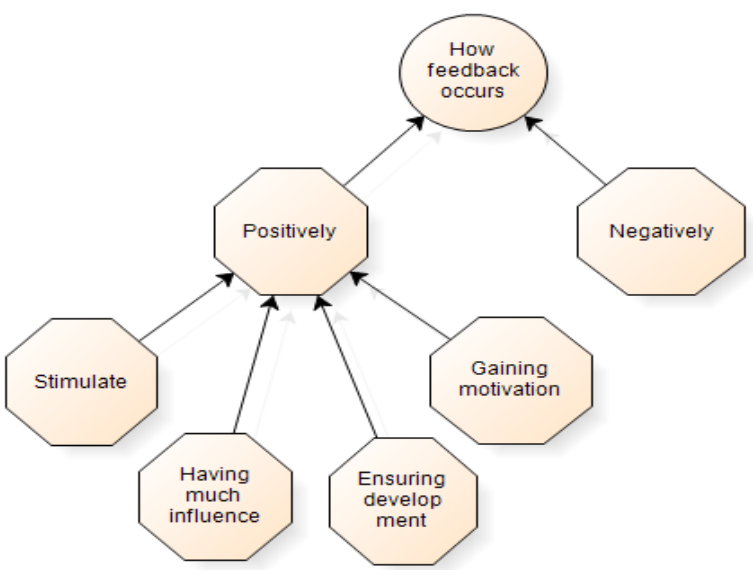

Model 8. Classifying feedback positive or negative

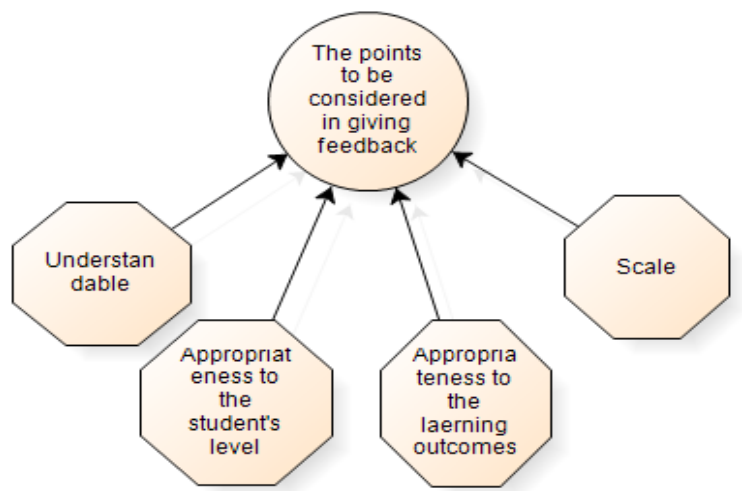

Model 9. Considering points for giving feedback

According to the results obtained from Model 9, 14 of the social sciencesteachers, pay attention to its being understandable in giving feedback, 6 teachers pay attention to its being suitable for the students' levels, 5 of them pay attention to its being suitable for the learning outcomes, and 2 teachers pay attention to the criteria. T10 who stated that $\mathrm{s} /$ he pays attention to the content of the feedback to be understood by the students pointed out that "I explain what we expect from the students clearly and suitable for their levels. If I ask whether they understand or not, I try to be sure that they have understood. If necessary, I ask them to repeat what I ask them to do. In order to make it easy to understand, I try to concrete and exemplify it." Another participant said that "Firstly, I 
observe which students understand the subject and how much they understand or do not understand through questions and answers. I choose the studies that I can do about it. For instance; I taught the subject of scale, I thought that everybody understood it. When I realised that there a lot of students who made mistakes, I taught the subject once more by solving the questions one by one."(T20)

As it can be seen in Model 10, 20 of the social sciences teachers prefer giving feedback at an average level, 7 of them give feedback by being selective, and one of them providesfeedback at a general level. The teachers who prefer givingfeedback at a reasonable level explained their reasons as considering crowded classes, discovering the students, ensuring a clear understanding, and students' levels. T18 pointed out about this subject that; "I give feedback at a normal level. Therefore, I do not interfere with the students' abilities and originality. I keep the level as easy as satisfying the students' simple needs." Some teachers stated that they make tiny distinctions in giving feedback to be ethical and for the benefit of the students. T20 expressed that "It depends on the subject's being understood or not. If I can not teach the learning outcome as I intended, I try to make the feedback level as I desire with various methods and techniques. I think that I am meticulous about it. In my system and opinion, everyone must learn and have an idea about the topic and make a comment." Some of the teachers stated that they are quite general about the content of the feedback that they give.
They pointed out that they prefer giving feedback at such a level since it is easy.

According to Model 11, 14 teachers stated that they use positive motivation, eight teachers use motivating feedback, four teachers use understandable feedback, and two teachers consider individual differences. The teachers who reported that they use motivating feedback explained that they use it to increase the students' level of success. T30 who is one of the teachers who use motivating feedback said that "I use positive and constructive because I don't think that students like judgmental and negative language. I think the best thing is that we need to guide them to take action together to reach the goal by showing them the difference between their performance and the goal." The teachers who use positive statement identified that they use positive feedback in order not to hurt students, to encourage them to study, and to motivate them. T2 who use positive statement pointed out that, "I give feedback by showing a positive approach and without hurting the student and showing that the given feedback is not just for him/her but for the whole class." T20 who said that s/he uses negative feedback explained that "Since I have an ambitious personality, I may sometimes react negatively, and this is never violence; however, I don't feel energetic when I do not see the expected student ambition. This does not last long. I think about what I should do; thissubjectwasn't comprehended, and by which way and method, I can teach this subject again.

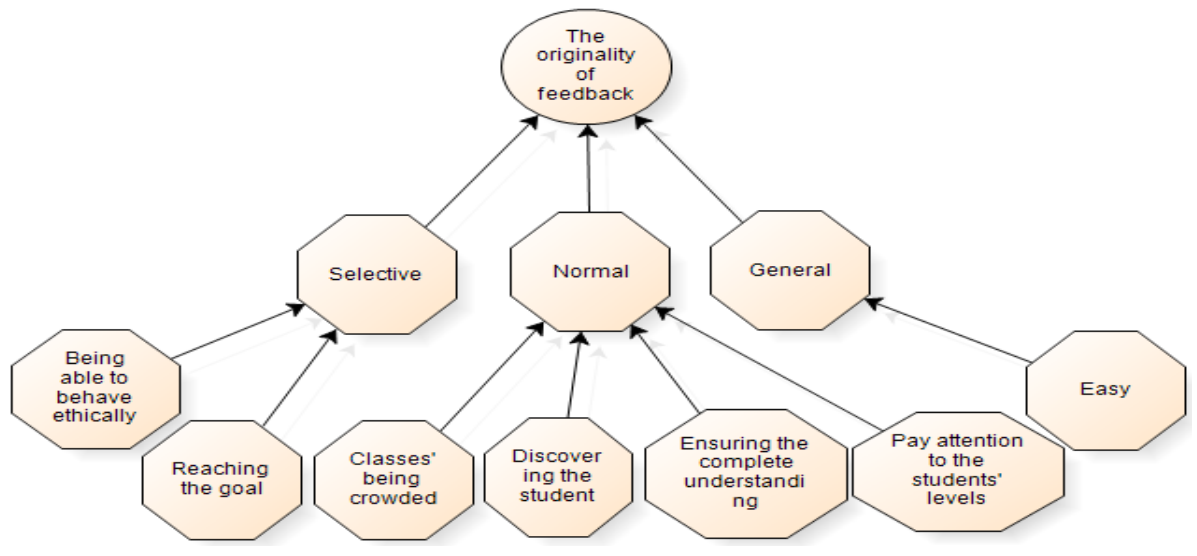

Model 10. The originality of feedback

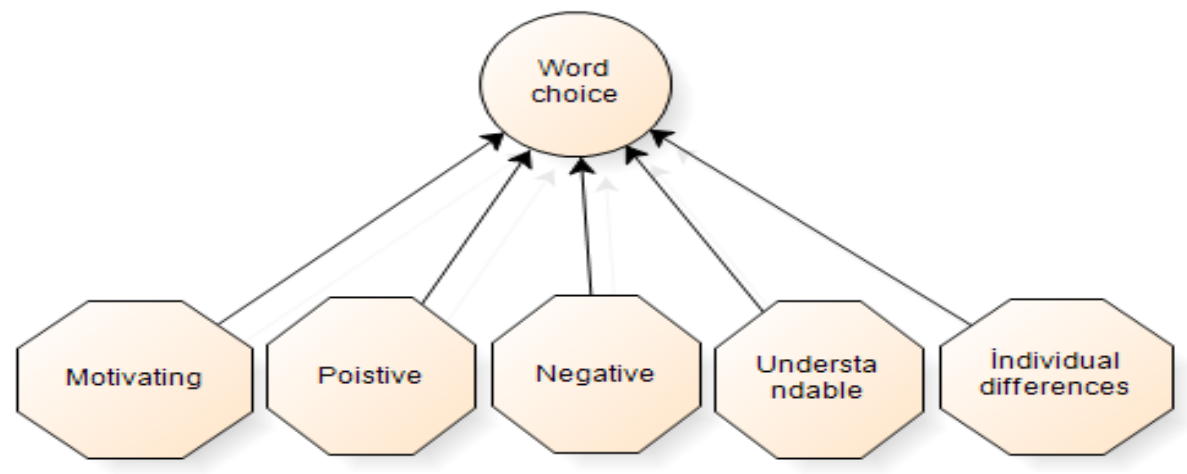

Model 11. The effect of language used in giving feedback 


\section{Discussion and Conclusion}

It is known that teachers' giving corrective feedback enables students to acquire learning outcomes more effectively. It can be inferred from the findings that teachers' feedbacks are affected by many factors including teachers' academic background, students' affective features, the content of the lesson and partners' academic perceptions. It can be claimed that teachers' feedback strategies are based on positive factors that will motivate students. While teachers develop supportive relations with students by using feedback strategies, they also give positive feedback. It is determined that positive feedback has various effects on the shaping of the students' existing learning and having more successful future learning. Positive feedback strategies are not only for motivating students' learning and behaviours, but also it is an effective way of changing the behaviours. When considered from this point of view, it is remarkable that the feedbacks obtained from the study are positive and corrective. It is seen that social sciences teachers give significant, corrective and positive feedback strategies to their students.

The aim of this study was to investigate the feedback strategies that social sciences teachers applied in their lessons. The research revealed that social sciences teachers mostly use verbal feedback, and they do not prefer applied feedback since it requires much time and effort. It was commonly known in the literature that teachers complain about the fewness of the course hours and the intensity of the subjects. Additionally, the fact that teachers do not have enough time to provide feedback or they can use only verbal feedback may stem from setting other educational activities related to the lesson to work. In one of the studies, it was pointed out that Turkish teachers use verbal feedback strategy most, and they stated that they use definitive statements in verbal feedback $[8-12,22]$. Considering the time teachers give feedback, they stated that they mostly give feedback at the beginning and at the end of the lesson consistently and in accordance with the learning outcomes. This result indicates that the teacher reveals the students' performance immediately with indicators and provides informative feedback at frequent intervals, and $\mathrm{s} / \mathrm{he}$ becomes efficient in it [7-10, 40,41,42]. In other words, it is clear that the teachers use feedback, correction and clues in accordance with the rules. It is observed that social sciences teachers determine the limits of feedback that they give to their students according to the students' features and their developmental levels; by this way, they make students participate the lesson actively. This finding shows that teachers use feedback, correction and clues which are among the feedback strategies efficiently. It may indicate that feedback and correction which are feedback strategies take place as an active learning instrument in learning and teaching process [17, 24, 25].
In other words, it reveals that the teacher uses the information process to learn at which level the students acquire the behaviour. It was pointed out that students can learn a lesson in a better way with reinforcement and they can maintain learning determinedly [15].

Besides, while teachers are determining the levels of feedback, they also consider its convenience to the learning outcomes. It was seen that social sciences teachers give feedback mostly individually. The teachers who prefer individual feedback explained their reasons for its being more advantageous for students and being easy, and they stated that group feedback is more beneficial for teachers. It was established as a result of the study that grading key is the most used scale by social sciences teachers in giving feedback. It was concluded that the teachers who mostly use this scale did not mention its reason. It was found that feedbacks given related to the student performance would fulfil amore evaluative function in students. In the feedbacks that social sciences teachers give to students, they usually have a positive attitude. All the teachers who give positive feedback stated that being in such an attitude, motivates students, encourages them, stimulates them, increases their self-confidence, and contributes to their personalities. In the study which carried out with $4^{\text {th }}$ and $5^{\text {th }}$ grades, it was concluded that the feedback given to the students during the educational process increases their motivation, informs them, makes up their deficiencies, and gives information about the levels of students [21].

It was inferred from the study that, social sciences teachers mostly give feedback at a reasonable level. There are also teachers who are selective and who providefeedback at a very general level. The teachers who give feedback selectively do this to be ethic and for the benefit of students. The number of the teachers who give feedback at a normal level is the highest. It was determined that they provide feedback at a normal level since it enables students to understand competing with themselves, it is suitable for the general student profile, and it facilitates reaching the target. On the other hand, feedback has an essential role in teaching training $[23,40]$. The results obtained from the study support the results that were obtained in previous years.

As a result, it was established that social sciences teachers prefer simple and clear language in giving feedback to students to be understood. Besides, it was found out that the properness to the learning outcomes and level of students are consideredin order toappreciate thefeedback. Lastly, it was determined that social sciences teachers use encouraging and motivating statements as well as positive and constructive statements. It was confirmed that teachers use encouraging and motivating statementsto make students understand that they are successful, to make them ambitious, and to contribute their level of success [40, 41, 42].

Based on the results obtained from the study, some 
suggestions have been made as below;

- It is always required to give students verbal and written feedback.

- Feedbacks should be given at the beginning and the end of the lesson.

- Students' level of success should be taken into consideration in giving feedback.

- It should be determined in advance whether feedback will be individually or towards a group and feedback should be given in this direction.

- Teachers should have a positive attitude in giving feedback.

- The language used in giving feedback should be clear and straightforward.

\section{REFERENCES}

[1] Ulusoy K, Dilmaç B. Değerler eğitimi (Values education). Ankara: Pegem A Yayıncılık, 2014.

[2] Sönmez V. Sosyal bilgiler öğretimi ve öğretmen k1lavuzu (Social sciences teaching and teacher book). Ankara: Anı Yayıncilık, 2010.

[3] Ergün M. Eğitim sosyolojisine giriş. (eğitim ve toplum) (Introduction educational sociology. education and society) Ankara: Ocak Yayınları, 1994.

[4] Bolat H. The effect of the teaching strategies proposed by Obenchain and Marris on the 6th grade students' academic achievements, attitudes and retention in the social sciences lesson. (Unpublished Master's Thesis). University of Çukurova: Adana, 2008.

[5] Kaya E, Öner G. Reconsidering social studies course in the axis of socialization and integrated education on its age of 100. Anadolu University Journal of Education Faculty 2017; $1(2): 1-25$.

[6] Erişen Y. The level of feedbacks and correction behaviors of education staff. Journal of Educational Administration1997; (1): 45-61.

[7] Cohen V.B. A reexamination of feedback in computer-based instruction: Implications for instructional design. Educational Technology 1985; 25, 33- 37.

[8] Hattie J, Timperley H. The power of feedback. Review of Educational Research 2007; 77, 81-112.

[9] Hattie J. A. Influences on student learning. Retrieved from http://www.arts.auckland.ac.nz/staff/index.cfm?P=8650, May 04, 2018.

[10] Marzano R. J. Classroom assessments and grading that work. Virginia: Association for Supervision and Curriculum Development USA, 2006.

[11] Lalande J. Reducing composition errors: An experiment. Modern Language Journal 1982; 66.2, 140-149.

[12] Robb T, Ross S, Shortreed I. Salience of feedback on error and its effect on EFL writing quality. TESOL Quarterly 1986; 20, 83-93.
[13] Sheppard K. Two feedback types: Do they make a difference? RELC Journal 1992; 23, 103-110.

[14] Kepner C.G. An experiment in the relationship of types of written feedback to the development of second language writing skills. Modern Language Journal,1991; 75, 305313.

[15] Can S. The role of clues and reinforcements in teaching-learning process. Journal of Social Sciences and Humanities Researches 2005; (14): 97-109.

[16] Baș G. Effects of gagné's model of events of instruction on students' academic achievement and attitudes towards english course. Journal of Uludag University Faculty of Education 2012; (1):433-457.

[17] Wu P.F. The effect of teacher training on the knowledge of positive behavior support and the quality of behavior intervention plans: a preliminary study in Taiwan. Universal Journal of Educational Research 2017; 5(9): 1653-1665.

[18] Somuncuoğlu D. The effect of different feedback strategies of computer-assisted teaching on learning. (Unpublished Master's Thesis). University of Ankara: Ankara, 1998.

[19] Tay B. The learning strategies of 4th and 5th grade primary school students in social sciences courses (Unpublished Master's Thesis). University of Hacettepe: Ankara, 2002.

[20] Uysal H. Learning strategies and learning strategy in the 4th and 5th grade new social science program (active learning) Yozgat province sample. (Unpublished Master's Thesis). University of Niğde: Niğde, 2007.

[21] Ayar T. Feedback in the process of education: evaluation of using feedback in the class according to the fourth and fifth grade teachers and students' respects. (Unpublished Master's Thesis). University of Cukurova: Adana, 2009.

[22] Çetinkaya G, Köğce D. An evaluation of secondary school Turkish and mathematics teachers' verbal feedback to students. Turkish Journal of Social Research 2014; 18(2): 113-136.

[23] Akalın S. Supporting teachers' professional development with performance feedback. Ankara University Journal of Special Education2014; 15(1): 57-68.

[24] Lans R.M, Grift W.J, Veen K. Individual differences in teacher development: An exploration of the applicability of a stage model to assess individual teachers. Learning and Individual Differences 2017; 58:46-55.

[25] Haukenes M.B. Feedback and assessment in the new kindergarten teacher education in Norway. Universal Journal of Educational Research 2017; 5(7): 1201-1214.

[26] Evans C. Making sense of assessment feedback in higher education. Review of Educational Research 2013; 83(1): 70-120.

[27] Lee I. Student reactions to teacher feedback in two Hong Kong secondary classrooms. Journal of Second Language Writing 2008; 17(3): 144-164.

[28] Burnett P.C. Teacher praise and feedback and students' perceptions of the classroom environment. Educational psychology 2002; 22(1): 5-16. 
[29] Montgomery J.L, Baker W. Teacher-written feedback: Student perceptions, teacher self-assessment, and actual teacher performance. Journal of Second Language Writing 2007; 16(2): 82-99.

[30] Zacharias N.T. Teacher and student attitudes toward teacher feedback. RELC Journal 2007; 38(1): 38-52.

[31] Annells M. Triangulation of qualitative approaches: Hermeneutical phenomenology and grounded theory. Journal of Advanced Nursing 2006; 56 (1), 55-61.

[32] Creswell J. W. Qualitative inquiry \&research design: Choosing among five approaches (3. ed). New York: Sage Publications, 2013.

[33] Büyüköztürk Ș. Sosyal bilimler için veri analizi el kitabı (Handbook of data analysis for social sciences)(10. ed). Ankara: Pegem A Yayıncılık, 2009.

[34] Yıldırım A, Şimşek H. Sosyal bilimlerde nitel araștırma yöntemleri. (Research methods in social sciences) (9. ed). Ankara: Seçkin Yayıncılık, 2013.

[35] Balcı A. Sosyal bilimlerde araştırma yöntem, teknik ve ilkeler. (Research methods, prenciples and techniques in social sciences) (11. ed). Ankara: Pegem A Yayıncılık, 2015.

[36] Büyüköztürk Ş, Kılıç Ç.E, Akgün Ö.E, Karadeniz Ş,
Demirel F. Bilimsel araștırma yöntemleri(Scientific research method) (1. ed). Ankara: Pegem A Yayıncılık, 2008.

[37] Ekiz D. Bilimsel araștırma yöntemleri (Scientific research method). Ankara: An1, 2009.

[38] Miles M.B, Huberman A.M. Qualitative data analysis. London: Sage Publications, 1994.

[39] Creswell J.W, Creswell J.D. Research Design: Qualitative, Quantitative, and Mixed Methods Approaches, Los Angeles: Sage Publications, 2018.

[40] Eriksson E, Björklund Boistrup L, Thornberg R. A categorisation of teacher feedback in the classroom: a field study on feedback based on routine classroom assessment in primary school. Research Papers in Education 2017; 32(3): 316-332.

[41] Snead L.O, Freiberg H.J. Rethinking student teacher feedback: Using a self-assessment resource with student teachers. Journal of Teacher Education 2017; https://doi.org/10.1177/0022487117734535.

[42] Crichton H, Gil F.V. Student teachers' perceptions of feedback as an aid to reflection for developing effective practice in the classroom. European Journal of Teacher Education 2015; 38: 512-524. 